\title{
CONTROL AND MANAGEMENT OF THE ECONOMY: RESEARCH PERSPECTIVES ON PUBLIC ENTERPRISE
}

\author{
By Y. P. GHAI*
}

In view of the pervasiveness of public enterprise and the variety of uses to which it has been put in the developing countries, it is surprising that there has been so little research on it. Few law faculties teach the subject in any systematic manner, and there are few scholars whose basic interest is public enterprise. An important institution and phenomenon has emerged on the legal scene without being noticed by most lawyers. The emergence of public enterprise confronts legal scholars with various challenges: that of formulating an adequate theory of public enterprise; that of empirical investigations (for as we shall see, the law tells only part of the story); of systematization; and of policy formulation. At a purely conceptual level, the challenge is obvious. Public enterprise cuts across traditional legal categories. It is a public agency and yet often operates through the medium of private law, it takes different forms and shapes, sometimes arising from the realms of public law and sometimes the private. It modifies, and is in turn influenced by, the legal environment for private enterprises.

Public enterprise has been called into existence to achieve a variety of vital national tasks. As more and more of the burden of national development is placed on public enterprise, the question of its efficiency and democratic control over it, becomes crucially relevant for the progress and of ten indeed the very viability of a society. And yet we know from experience that the record of public corporations is of ten poor; not only have they failed to generate surpluses but have in fact of ten squandered scarce public funds, while at the same time (this tendency increases as the enterprises are financially successful) they may become empires unto themselves and resist any public accountability. They are a breeding ground for corruption and nepotism. Most countries are engaged in the search for better policy and its implementation in the public economic sector, and many of the problems which have arisen are of direct concern to the lawyer, e. g., institutional structures, the relationships between institutions, the appropriate role of civil and criminal liability in new situations, the balance between autonomy and control.

Central though these issues might be to the world of law, it is argued that research on them will have to be cast in a broad framework that transcends law if a genuine understanding of these issues is to be arrived at. A legal-doctrinal study, pre-occupied with forms and structures, is unlikely to provide an insight on how the enterprise functions, and therefore unlikely to suggest solutions or policy which have any real relevance. One has to look at the world of rules, and then the universe of action, and then back to the rules, if one is to make a useful contribution to knowledge and policy about public enterprise. In a situation where the legal rules are inadequately developed, or not truly

\footnotetext{
* I am grateful to the Swedish Council for Social Science Research for support towards this study. I am also grateful to the International Legal Center, New York for its support in the past.

A number of individuals have commented on earlier drafts of the paper, and I am most grateful to them for their help. I would like to mention in particular Richard Abel, Ranjit Amerasinghe, Anthony Bradley, Terence Daintith, Reginald Green, John Howard, Patrick Mc Auslan, Pheroze Nowrojee, James Paul and William Whitford.
} 
reflective of practice, or where legislative formulation can hide true purposes ${ }^{1}$, it is especially important to adopt such an approach. The framework within which research on public enterprise is carried out must incorporate the environment external to the public enterprise. The external environment must include but not be confined to the general political economy. The internal, formal and legislative provisions cannot be appreciated except in the general, larger political economy context. Public enterprise is a devise capable of different uses, and these uses are determined by various factors. Key amonog these are the mode and the realizations of production, the nature and alliances of the ruling classes, and the access to and control over the state apparatus. Ultimately, the functions of public enterprise must depend on the nature of the state. This helps to explain the apparent paradox that both countries with socialist as well as capitalist aspirations employ the device so extensively. There are wide ranging similarities in institutional and structural arrangements, a factor which tends to mask the important differences in purpose. The political economy helps to define the purposes. But it does more. It explains the constraints within which public enterprise operates. To a large extent, public enterprises in developing countries reflect the weakness of the general economy (which they are allegedly set up to redress), and its inability to achieve an autonomous growth. But it is easy to see the weaknesses and failures as those of public enterprise, if not actually inherent in them, rather than as endemic to the situation of many developing countries. In particular the foreign external constraints are overlooked, although many of the problems of public enterprise are the result of the weakness of the national economy due to its dependence on the international system ${ }^{2}$. The external factors are also germane in that many public enterprises are really forms of joint venture with foreign private capital, and have come increasingly to constitute an essential component in the legislative and administrative regimes for foreign private investment. They are not all public enterprise. Just as in many western countries, the infusion of state capital and control in the economy through the organisational forms of private enterprise serves to hide the degree of state subsidisation and interference in economic enterprises ${ }^{3}$, so in many developing countries, the use of public enterprise forms by private groups tends to hide the dominance of private and generally foreign interests.

It is important to bring another perspective to the study of public enterprise, as indeed of all legal phenomena. Laws call into existence particular institutions, and give them particular forms. But how these forms develop and how the institutions operate is not easily controlled or influenced by the law. Much legal as well as social science research is dominated by an instrumental view of law, with somewhat

\footnotetext{
1 See Fedder, "Counterreform" in Stavenhagen (ed.), Agrarian Problems and Peasant Movements in Latin America, 1970. Fedder's study deals, inter alia, with public agencies charged to implement programmes of land reform.

2 It can be said in general that there are two schools of thought on why public enterprise has been largely unsuccessful. One looks at the structure of the enterprises, the lack of managerial capacity, and governmental interference and political corruption. For examples of this approach, see Pozen, "Public Corporations in Ghana: A Case Study in Legal Importation", in 1972 Wisconsin Law Review 802-844; and the essays on public enterprise in A. H. Rweymamu and G. Hyden, A Decade of Public Administration in Africa, 1975. The other school attributes the failure to the negative influences of foreign capitalist interests and the dependency of the third world countries on the international economic system. Examples of this approach include Issa Shivji, "Capitalism Unlimited: Public Corporations in Partnership with Multinational Corporations", Vol. 3 The African Review (1973) 359-381; Kwesi Botchwey, "The Dynamics of Public Corporate Activity in Contemporary Africa', (unpublished paper).

3 See Friedmann, "Public and Private Enterprise in Mixed Economies: Some Comparative Observations", in W. Friedmann, Public and Private Enterprise in Mixed Economies, 1974.
} 
unidimensional notions of its purpose, agencies and sanctions. But once an institution has come into existence, it is subject to various pressures and pressure groups, and can often be co-opted by interests which it intended to fight or moderate. It is seldom possible to predict the consequences of a law, for it is difficult, if not impossible, to draw a complete map of the relevant universe. The dynamics of an institution or law have to be carefully observed and analysed. It is particularly important in research on public enterprise that a complex set of institutional relationships, range of decision making, interest groups, changing political and economic complexion of ruling elites, are recognised and taken into account.

The importance of public enterprises lie largely, although not exclusively, in their impact on the economic system. But it is of course not the only form of state intervention in the economy, although it is among the most visible. The building of the infrastructure through the use of state revenues, concessional fiscal rates, and even the support of the freedom of contract are forms of state intervention. It will help to arrive at a theory of public enterprise if one looks at it as one of the several forms of state intervention in the economy. In an interesting study, Seidman has tried to show how extensive state intervention, often through various forms of public enterprise, was necessary in Kenya for the exploitation of the colony by the British, while the same purpose was achieved in Ghana without such direct intervention, was indeed achieved through permitting the legal freedom to contract ${ }^{4}$. Public enterprise for state participation in industry may be a new form, but it is a new form for old purposes: the intervention of the state to achieve certain social, political and economic goals. While this illustrates that the state is never neutral and that it encourages, promotes or induces certain form of growth, favouring particular groups or classes, problems that public enterprise gives rise to are qualitatively different from those caused by other forms of state intervention. In such a context, it is worthwhile to examine the alternatives to public enterprise, and to make an attempt as to why this is becoming the preferred form.

It is suggested that research on public enterprise would profit from paying attention to themes and propositions set out below. Many of the propositions are meant to start lines of enquiry, rather than be taken as definitive conclusions. Nor is it my purpose to suggest that most of the questions and issues traditionally discussed and analysed by lawyers are irrelevant or not worthy of attention. This paper is essentially a plea to place these problems and issues in a wider context, so that the relationship of legal to societal issues becomes clearer. The paper does not claim to cover all the issues which are relevant to an understanding of public enterprise in this broad context.

\footnotetext{
4 R. B. Seidman, "Contract Law, the Free Market, and State Intervention: A Jurisprudential Perspective", Vol. VII Journal of Economic Issues (1973) 553-575. Seidmnn probably underestimates the surplus retained by Ghana's cocoa farmers. There is some evidence that cocoa generated considerable income for a class of cocoa farmers. See Polly Hill, The Migrant Cocoa-Farmers of Southern Ghana, 1963; R. Fitch and M. Oppenheim, Ghana: End of an Illusion, 1966.
} 


\section{Public Enterprise and Other Forms of Control}

Form and structure are happy hunting grounds of lawyers. In particular much ink has been squandered on whether the departmental, public corporation or the company form is the most appropriate form for public enterprise. It is proposed that the debate about the form and structure should be cast in a wider framework. At least two dimensions need to be explored. One is the choice of the public enterprise form as opposed to other forms of state intervention (which will be discussed in this section) and the other is a set of issues internal or closely related to public enterprise form (which is discussed in a subsequent section).

The question may be raised, why is public enterprise becoming (as it seems to be) the preferred form of state intervention in the economy. A variety of reasons are given for the establishment of public enterprises: to fill the gaps left in the economy by private enterprise, either because of the size of investments required or because of the unprofitability of the project, to provide a basic infrastructure for the economy, to promote greater national economic independence, to provide some measure of check over or at least competition to the private sector, to obtain greater control over the economy, to ensure a more balanced distribution of industry and its rewards. It may be argued that public enterprise is not a sine qua non for the achievement of these purposes, except in one case. If policy is to create a socialist economy, there is likely to be little alternative to public enterprise, where it is a necessary but not sufficient condition. But in very many countries, the purpose is often the very opposite: paradoxically, state enterprise is used for the development and strengthening of the private sector ${ }^{5}$. In so far as the general aim is the control or guidance of the economy, other tools are available. The "alternative approach" would look at the various kinds of control open to the government with a view towards some cost and benefit analysis. Various regulatory or prohibitory methods may be able to achieve as much with greater economies of time or money. The "alternative approach" would emphasise the importance of clarifying the objectives of public enterprises, and establishing the criteria for evaluation of success.

One can draw two models of control of an economy. The first is where the state does not itself take over any sectors of the economy, but seeks through a variety of regulatory and other mechanisms to influence the conduct of the economic actors, who are private parties. The other model is where the state actually enters into production, and moves from control to the management of the economy. These models do not exist in isolation, one from the other, and indeed given the mixed economy of most developing countries, they exist side by side, sometimes reinforcing each other, and sometimes in some degree of confusion, if not actually in antagonism ${ }^{6}$. But these models do approximate to two different modes of organising the economy, each with its own distinct characteristics, and

5 For a detailed study of how this has been done for Kenya, see P. Nowrojee, "Public enterprise and cooperatives in Kenya and Tanzania: Some comparative illustrations", Vol. 5 Eastern Africa Law Review (1972) $141-175$.

6 Various sub-issues arise. What is to be the mix between public and private sectors? Should a government aim at a 100 per cent ownership of a limited number of enterprises or a smaller share of a larger number of enterprises? How far should the regulatory mechanism be relaxed in its application to the state sector? For a discussion of some of these issues, see E. Penrose, "Ownership and Control": Multinational Firms in Less Developed Countries", in G. Helleiner, The Third World and International Economic Change, forthcoming, and R. H. Green, "The Peripheral African Economy and the MNC", in C. Widstrand, (ed.), Multinational Firms in Africa, 1975. 
it is worthwhile examining them as alternative forms of control over the economy. The regulatory model is characteristic of private sector economies in the developing countries, although the regulatory model can also be applicable in socialist countries $^{7}$. The regulatory model operates through a variety of controls on the private sector. These controls are administered by the government or its agencies. There is little systematic study of the controls or their operation, despite their pervasiveness. Myrdal has an interesting study on operational controls over the private sector in South East Asia, particularly India, and his suggestions and insights provide a good starting point for research in this area ${ }^{8}$. Operational controls arise from the desire to control the development of the economy. In certain instances they also arise from the general weakness of the market mechanism, as in the industrialised enclave, or even the absence of the market mechanism, as in subsistence agricultural sectors. Finally, they arise from the existence of scarcities, of raw materials, foreign exchange, etc., requiring some method of determining and servicing priorities. In each case, the intention is not to let things take their own course, but to influence or control economic developments. Myrdal classifies controls into positive and negative, and discretionary and non-discretionary. Positive controls seek to promote some particular activity: examples are tax incentives, remission of import duties on raw materials, subsidisation through the price machanism or more directly, etc. Negative controls seek to prohibit or restrict particular activities; examples are laws requiring licenses for investment, borrowing, expenditure of foreign exchange, exercise duties, etc. As Myrdal recognises, there is no neat distinction between them, for what is negative control for one person may be positive control for another. As an example, one may take now defunct East African Industrial Licensing system, under which production of certain manufactures could only be undertaken after a license from a licensing council. The effect of the system was to seriously restrict manufactures of the prescribed items, but the whole justification of the system was its positive character. By ensuring to a licensee a monopoly or semi-monopoly position, it was hoped to induce him to undertake investments and production ${ }^{9}$. Discretionary controls are those which depend for their application on a decision of an official or committee, who has more than one option. Non-discretionary, by contrast, operate independently of the official; they are prescribed by law or some other general norm, and apply to and are available to all those who come within its ambit. Examples are bank rates, excise duties, tariff rates, and the general structure of tax Legislation. They establish standards, and eliminate the need for decisions on individual cases or applications. Myrdal has a clear preference for the non-discretionary controls for they impose less of burden on the bureaucracy, are easy to administer, give the parties concerned advance notice of the framework within which they have to make planning decisions, minimise opportunities for graft or corruption. In practice, discretionary controls

\footnotetext{
7 Under the recent changes in economic systems of several socialist countries, there is now considerable reliance on the regulatory mechanism although the basis of ownership remains public. See Eörsi and Harmathy (eds.), Law and Economic Reform in Socialist Countries, 1971;

There are indications that Tanzania, which has a substantial public sector, is beginning to employ the regulatory mechanism for the public sector, e.g., The Prices Act (1973) and the Companies (Regulation of Dividends and Surpluses and Miscellaneous Provisions) Act (1972).

8 Gunnar Myrdal, "Operational Controls over the Private Sector”, in The Asian Drama, Vol. II, 1968.

9 Y. P. Ghai, "East African Industrial Licensing Council: A Device for the Regional Allocation of Industry", Vol. XII Journal of Common Market Studies, (1974) 265-295.
} 
tend to be the more common variety. Myrdal finds a basic reason for this in the desire of politicians and bureaucrats to arrogate power to themselves, and in an aquiescene of or collusion by the big business houses, who are able to manipulate the system to their advantage, at the expense of the smaller firms ${ }^{10}$. Myrdal concludes that the system of operational controls do not achieve their purpose: there is little co-ordination of the various controls, so that often one tends to cancel another ${ }^{11}$, there is a cumulative tendency towards the discretionary controls, which leads to a complex and cumbersome system, and that the system is susceptible to manipulation by interest groups and is used for purposes different, if not actually contrary to those intended.

Myrdal's study points to the dilemma, if not the contradiction, of planning in a dominantly private enterprise economy. But more than planning is sought; it is desired that there be some measure of control. In addition to the reasons that Myrdal gives, it could be argued that planning and control are difficult because we are talking of economies which are in no sense autonomous, and are subject to numerous foreign influences: capital, technology, markets. Under the circumstances, we may say that the search for control of the economy must lead us in different directions, one such direction being public enterprise. It is possible to explain the mushrooming of public enterprise in Tanzania in 1967 as a response to the failure or inadequacy of the regulatory mechanism. The Tanzania economic strategy after independence was the classic one of the state subsidising of and regulating the private sector. Increasing dissatisfaction with the progress of the development plan based on that strategy led to a fundamental re-examination of problems and options, and resulted in the emergence of public enterprise. More than the control of the economy was, however, at stake in the Tanzania decision, as public enterprise was also seen as the key in the transition to socialism.

Public enterprise, is, however, also used to bring about greater governmental control when there is no particular hostility to the private sector. In such cases public enterprise can be used to allocate resources on a differential or discriminatory basis, as in Kenya or Malaysia to promote the development of particular sections of the population ${ }^{12}$. In Kenya this has been combined with the regulatory method for in 1967 various laws were passed to prohibit or restrict the employment of or commercial practices by the non-citizens. The importance of public enterprise was at least twofold: the regulatory mechanism as set out in the trade licensing, immigration and employment legislation, was seen as a necessary but not sufficient condition for the emergence of African commercial classes. More positive material help had to be provided, like capital and technical services, which was done through public agencies. The second reason was that public agencies provided the government with additional centres of influence and power, for even within the general class of beneficiaries of the regulatory legislation, distinctions could be made on an administrative rather than strictly legal basis ${ }^{\mathbf{1 3}}$. In other words, public enterprise forms a basis of patronage and a more tightly controlled allocation of resources.

10 For a defence of discretionary controls, see R. H. Green, "Law and Economic Planning in Africa, 1975 (unpublished).

11 As Myrdal puts it, this is like driving a car with the accelerator pushed to the floor but the brakes on, p. 925 , op. cit.

12 For Kenya, see Nowrojee; for Malaysia, see Jaginder Singh, "Public Enterprises and their Legal Structure in Malaysia", forthcoming in Amerasinghe (ed.), Public Corporations in Asia. 
Public enterprise when married with private business in the form of joint enterprise may also provide a better basis for the control of the private sector. The government may thereby get increased access to important commercial information. It may minimize opportunities for over-invoicing, price-transfers, and tax evasion. It may be able to influence policy at the directly policy making levels. As Green has said, national capacity - whether in respect of financial mobilisation, technical and research expertise, or high level manpower - depends on a host of decisions at firm level, it can hardly be enforced bureaucratically without a host of rules and of skilled personnel. "The latter at least are lacking in Africa and the former alone will prove either ineffective or economically damaging to the foreign firm and the host economy alike ${ }^{14}$." There is the counter argument that joint ventures not only result in the private partner making the key dicisions in the context of a weakened or less rigorously enforced framework of control, but that whatever potential for control might exist by virtue of capital available to the government is squandered as joint ventures effectively de-nationalise state capital ${ }^{15}$. We come back to this debate when we focus on the role of international capitalism in public enterprise.

Public enterprise is said to offer possibilities of control through providing alternative and competing institutions to those of the private sector. A vigorous and competitive public sector can establish new standards to which the private sector will be pressed to conform. Public enterprise can thus promote greater efficiency, competitiveness, and can be used to exact a greater responsiveness to national policies on the part of the private sector. It may of course be difficult to create a vigorous public sector with the capacity to discharge such functions, especially if it is to be treated on a par with the private sector, as it would need to if it is to establish a model for the private sector. The thinking behind Nkrumah's public enterprise was of this kind, and proved very difficult to implement, since the public sector starts with various handicaps ${ }^{16}$.

From a juristic point of view, somewhat simplistically stated, the difference between the regulatory and the public enterprise strategies is that the former is a method of control without ownership, the latter of management without ownership. Iis true that the autonomous character of a public enterprise may mean that the method is still of control and not management, from the government's point of view, but the public ownership of the means of production very likely or perhaps inevitably leads to the blurring of the distinction. It is easy to believe in some circumstances that the only method of control is through management. In the regulatory control mechanism, the pull is towards generalised rules, even if there are large elements of discretion vested in the officials, whereas in the management method, broad discretionary power is essential. (It may be that

13 In Kenya's case, the constitutional provisions of equal protection would render it difficult to apply the regulatory mechanism in the way it was really intended, i.e. to discriminate against all Asians, whether citizen or not. See Fernandes v. Kericho Liquor Licensing Court, (1968) E. A. 640, Mahdwa v. City Council of Nairobi (1968) E. A. 406; Shah Vershi Dewjiv. The Transport Licensing Board 1970 E. A. 631.

14 R. H. Green, "Economic Independence and Economic Co-operation", in D. P. Ghai (ed.), Economic Independence in Africa, 1973. Cf. views in Penrose, op. cit. (footnote 6). Hanson argues that the proliferation of enterprises poses a problem of directive and oo-ordination which "might well tax the capacity of the most competent of bureaucracies", Public Enterprise and Economic Development, 1965,

15 S. 349. Saul, "The Political Aspects of Economic Independence", in D. P. Ghai, op. cit., Shivji, op. cit., A. G. Sawyerr, "Multinational Corporations and Economic Development in Underdeveloped countries: The case of the Rubber Industry in Ghana" (unpublished).

16 Fitch and Oppenheim, op. cit. 
when the public sector becomes large or dominant, management' has also to operate through generalized rules, as at this point there has to be a significant decentralization of economic decision-making). We spell out some of the legal implications of this distinction in a later section, but state here that public enterprise represents an aggregation of important resources under governmental control. It leads to the creation of direct economic power at the disposal of the government, whose essential purposes may be largely political. Whether political or economic, the creation of economic power poses a number of problems and issues for the investigation of which public enterprise provides a useful starting point. The concept of economic power is of course wider than that of public enterprise narrowly defined, for it would also include ad hoc, individualised, administratively determined intervention $\mathbf{s}^{17}$. One reason for the choice of the public enterprise form therefore over that of the pure regulatory method may lie in the additional levers it provides even if they are no more effective. Just as regards the rest of the legal system in Africa, the autonomy of the legal system is increasing mitigated, qualified and eventually removed, by administrative and political directions and decision making, so the public enterprise is seen to be more predicable, and more immediately controllable than operation through generalised standards ${ }^{18}$.

This is not to say public enterprise is necessarily more successful in the control of the economy than the alternative ways. Various studies in different parts of the world have shown that public enterprises have squandered scarce resources, led to new bureaucracies, and given little effective power over the economy. It may be that at bottom both the regulatory and public enterprise strategies suffer from the same basic problems and weaknesses: dominance of the external, largely foreign environment, corrupt and powerful local elites, who in collusion with foreign interests, manipulate the local economy for narrow class or group purposes, unresponsive political systems. The various implications of this position are examined in the following sections of the paper, including the alleged implication that law is exhausted as a category if this analysis is right.

\section{The State, Classes and Public Enterprise}

It was argued earlier that as public enterprises are in a sense a direct emanation of the state, it is important to focus on the nature of the state for a true understanding of the purpose and operations of public enterprises. The focus on the state is important for various reasons. One, while public enterprise may give the impression of the state becoming involved in the economy, the fact is that the state is always involved in the economy, and the interesting point about public enterprise is why and when the state uses this form as opposed to other modes of

\footnotetext{
17 I am indebted to Professor T. C. Daintith for the concept of economic power, in a private communication. See his paper, "Public Law and Economic Planning", Journal of Business Law, Jan. 1974, $9-22$.

18 The concept of the autonomy of the legal system is difficult and somewhat ideologically charged. I use it to mean not that the legal system is completely separate from and independent of the political and economic systems (which it clearly is not), but that a legal system is a form of decentralised decisionmaking in which by and large rules are established in advance and decision-making institutions apply these rules in coming to a decision. Although this is a simplified description, it suggests that once the norms have been established, there is little day to day, ad hoc intervention with the institutions. The autonomy of the system is reduced as the government relies upon more direct forms of intervention and direction.
} 
intervention ${ }^{19}$. Second, the state is no abstract or neutral entity; it is a politicoeconomic apparatus which is controlled and manipulated by certain groups; public enterprise would be used to enhance the interests of the groups which dominate the state, and may quite often be used to strengthen the capitalist system. Third, especially in the case of many developing countries, the state may be in the position of influencing the formation of classes and interest groups. The concept of economic power, which was developed earlier, is a key one here, for it is by use of the state apparatus that economic power is called into being in many developing countries, as opposed to the developed countries where the private economic power of ten created and used state economic power ${ }^{20}$. Various studies have looked at the class interest in the use and manipulation of public enterprise ${ }^{21}$. The most extended study is Shivji who has argued that the public enterprise has been used in Tanzania to break the economic strength of the Asian and foreign groups, and then used by the "bureaucratic bourgeoisie" to entrench itself as against both other elements of the petty bourgeoisie and workers and peasants ${ }^{22}$. Leys has analysed the use of public enterprise in Kenya to show its crucial role both in the promotion of an African commercial class, and in the mediation with international capitalism. He has shown that merely protective legislation was not enough to promote African business; public enterprise was called in existence to provide more direct, operational assistance. At the same time he shows the limited role that has been ascribed to public enterprise, for public enterprise functions within a framework in which the dominant role in the economy has been ascribed to foreign capital23. The first venture of Nkrumah's government in public enterprise, the Cocoa Purchasing Company, was used as an instrument to promote the ruling Convention People's Party. The resources at its disposal were used to buy votes for the party; those applicants who could show no affiliation to the party were denied any assistance. "In this way, the CPP took advantage of the small farmers' financial predicament to build a patronage machine. Politically screened farmers not only were given instant credit, but if their loans fell into arrears, no penalties accrued. Loans were given in excess of

19 This point has already been touched on. For a discussion of state intervention in colonial East Africa, see EA Brett, Colonialism and Underdevelopment in East Africa, 1973.

20 For an attempt to formulate the functions of the state in capitalist development, see Robin Murray, "The Internationalisation of Capital and the Nation State", 67 New Left Review May-June 1971, 84-109.

21 See Saul and Loxley, “The Political Economy of Parastatals”, Vol. 5 Eastern Africa Law Review (1972) 9-37, for an attempt to place the public sector in the political economy context.

22 Issa Shivji, Class Struggles in Tanzania, 1976. Shivji argues that it was necessary for the pettybourgeoisie in Tanzania to use the state to nationalize industry and to restrict activities in the private sector as a means of enriching and entrenching itself (as opposed, for example, to the situation in Kenya where the same class has been able to promote its interests through the private sector) because it was a weak group with a poor economic base due to the relatively limited colonial penetration in Tanzania. (John Saul has questioned this thesis, by arguing that the immigrant commercial and industrial groups in Tanzania were also correspondingly weaker than their Kenya counterparts, "The State in Post-Colonial Societies: Tanzania" (pp. 361-362) in Miliband and Saville (eds.), Socialist Register, 1974). What is more probable is not that public enterprise was used to entrench the group (class?) in question, but that once public enterprises were established (for nationalist or socialist reasons), elements of the bureaucracy tended to use them to enhance their own privileges.

The use by the bureaucracy of the mechanism of the state to enhance its own interests has also been noted by Claude Meillasoux in Mali. He writes, "Once established in a governmental position, this social body (i. e., the bureaucracy) had to take several steps, both to gain certain positions of control in the modern economy and to eliminate opposition spreading from the Malian historical classes. One of the first steps was to infiltrate the national economy through the creation of a nationalized economic sector. This was done under the label of "socialism" which provided them with a convenient ideology to bring the economy under their control, supposedly on behalf of the entire population. "Socialism" permitted them to put the bureaucracy into the position of a management board of a kind of State corporation", p. 106, "A Class Analysis of the Bureaucratic Process in Mali", The Journal of Development Studies, 1970, Vol. 6, No. 2 (97-110).

23 Colin Leys, Underdevelopment in Kenya: The Political Economy of Neo-Colonialism, 1975, esp. chap. 5. 
statutory limitation ${ }^{24}$." The use of public enterprise for patronage purposes in Nigeria has been well documented ${ }^{24 a}$, so much so that Udoji has declared seriously that it would be a good idea if governments were free to distribute a certain number of sinecures, to pay off political debts, etc., instead of using appointments within the public sector for this purpose ${ }^{25}$. Schütte has discussed the use by political and bureaucratic elites in Northern Nigeria of public corporations to further their own interests, and points out that the Nigerian corporations have been a device to extract a share of the profits of the peasants and farmers, to be used for the enhancement of other groups, particularly the commercial and industrial26.

While it is thus clear that public enterprise has to be seen largely in political terms, there is unfortunately limited analysis of the nature of the state in the developing countries, of class formations, and of the precise uses of public enterprise 26a. It is important to distinguish the use of public enterprise as a minor spoils system from its use to systematically build up an economic base for a political or other group. There is similarly a tendency to lump too many of the elite groups together, as if they were a class with common interests ${ }^{26 b}$. Certain clarifications are necessary if more light is to be thrown on the issue.

The central importance of the state is well recognised. Both Leys and Shivji refer to the Bonapartist situation in many African countries, when the social groups are fluid, are in the process of formation, and where access to and even more, the control of, the machinery of the state is crucial27. Those who have the control of the state, the political and bureaucratic groups, are identified as the important groups, often as.members of the same class. It is stated that these groups do not have an independent economic base, but use the state resources to build one, and hence is referred to as the "bureaucratic bourgeoisie 28 ". This approach has been criticised by several writers. Green has argued that it is wrong to lump the bureaucracy and the political elites together, and that the power of the bureaucracy has been exaggerated" ${ }^{2}$. Leys considers "the important point about the higher echelons of the state apparatus is less their class origins or ambitions than their specific function in relation to the ruling alliance of classes and class

24 Fitch and Oppenheim, op. cit.

24a The use of public enterprises for political patronage and other political purposes is the theme of many official enquiries and commissions in West Africa. One of the best known of these is the Coker Commission of Inquiry into the affairs of Certain Statutory Corporations in Western Nigeria (1962), which alleged widespread use of public enterprise and their funds to support Chief Awolowo's Action Party. In the then Eastern Nigeria, Azikiwe was accused of similar practices, Report of the Tribunal Appointed to Inquire into Allegations Reflecting in the Official Conduct of the Premier of, and Certain Persons Holding Ministerial and Other Public Offices in the Eastern Region of Nigeria, 1957, London.

$25 \mathrm{~J}$. O. Udoji, "Some Measures for Improving Performance and Management of the Public Enterprises", in Rweymamu and Hyden, op. cit., at p. 248-249. "A possible solution lies in the creation of a few sinecure posts which politicians can fill at their pleasure. What is being suggested is something like the post of the keeper of the Tower of London or that of honorary chairman of the french parastatal bodies. The posts carry good salaries but hardly any responsibility."

26 Heinz Schutte, "Public Corporations and development: The case of the Northern Nigerian Development 26a But see Shivji, op. cit., Hamza Alavi, "The State in Post-Colonial Societies - Pakistan and Bangladesh", in New Left Review 74 (July-August 1972) pp. 59-81, and John Saul, “The State in Post-Colonial Societies: Tanzania", in Miliband and Saville (eds.), The Socialist Register, 1974, pp. 349-372.

26b Thus Shivji treats the bureaucrats and political and party leaders as one group, although in 1970 in his Tanzania: The Silent Class Struggle, he had made a distinction between the bureaucrats and the party leaders. He had also made a distinction between the "economic bureaucrats", i. e., the managers of the public enterprises, and the civil servants, and had predicted that the former would dominate the latter. In Tanzania, as well as some other countries, the civil servants in fact have tried to keep a firm control over the managers of the enterprises, and have been among the chief groups to attack, and reduce, the privileges of the latter.

Corporation", Vol. IX East Africa Journal (April 1972) pp. 21-27.

27 The reference is to Marx's analysis in the Eighteenth Brumaire of Louis Bonaparte, 1852.

28 Shivji, Saul, op. cit.

29 Green, "Law and Economic Planning", op. cit. 
strata. Concentrating on the tendency of state officials to try to acquire property is apt to divert attention from this more important point ${ }^{30}$." According to him the Kenya bureaucracy understood the operation of modern economies, the aggregation of resources in corporations, the relationship between different modes of production, and their own key role as bureaucrats in determining these relationships. In other words, they were more involved in the classical functions of the state and its bureaucracy, than that of a class of entrepreneurs. To some extent they determined the access of the latter to state resources. Perhaps the most striking criticsm has come from Szentes who questions how far the elite can be called a class or even a class in formation, since it does not really have the means for the reproduction of itself as a group. "The real question is not whether the emergence of the elite is or is not a source of class formation, but rather: for what class it is a source and whether this is a new and independent one ${ }^{30 a}$ ". It can either promote capitalism, in which it will become part of the bourgeoisie rather than an independent class, while if it fights against capitalistic relations of production, as well as against socialistic development, the outcome is complicated, but unlikely to be that of a selfperpetuating bureaucratic or managerial elite.

The Bonapartist analysis leads to a conclusion somewhat different from Shivji: a fluid and somewhat changing constellation of interest groups. The dominant groups are seldom totally united on all points; they compete as often as they collaborate; the alliances shift; some ruling groups are more coherent than others. Green has proposed analysis in terms of "ruling coalitions" and suggested that coherence and consistency in policy will vary with the security which the coalitions feel and enjoy. Thus the Nigerian and Sudanese coalitions manifest confusion and inconsistency, as contrasted with the Kenya and Tanzania ones. The notion of "coalitions" also suggests that various groups have to be placated at various points, and that policy does not always have a sharp and unidimensional edge. Sometimes the coalition is unclear as to what it wants, or how to get it. This is one explanation of the mess of public enterprise under Nkrumah, at least in his early years. On the other hand, the establishment of a public sector, especially if it is justified by socialist or nationalist motives, may have a tendency to increase pressures for progressive policies, despite the intentions of the coalition. (Shivji recognises this as one of the few positive results of the Arusha Declaration and nationalisations following it.) Moreover, as the size and importance of the public sector increase, the stability of the coalition becomes tied to the success of that sector. Narrow and immediate class interests may then need to be sacrificed to "wider" progress and development to placate public opinion and to maintain credibility in the policies of the government. It is also possible to imagine an important or even a radical change in the situation which would change the purpose of public enterprise (as indeed of laws generally). In his later years as President, Nkrumah was beginning to use public enterprise in a more coherent manner with socialist aims, while Chile provides an interesting case study of the effect of a changed ruling group on the use of public enterprise. Chile has had for a long time a general development purpose public corporation (it is in fact the oldest general

30 Leys, op. cit., p. 191

30a Thomas Szentes, "Status Quo and Socialism", in The Silent Class Struggle, 1973, at p. 102. 
development corporation in an LDC). It was set up to help strengthen the free market system, and one of its important functions was to establish new economic enterprises and when they were successful, to sell them to private groups. But when Allende came in power, it was one of the principle means whereby he was able to bring banking, steel and other important areas under the state sector, since he was unable to get new legislation from the Congress. Similarly, the independent Kenya government has been able to use some colonial legislation which was intended to prevent the economic development of Africans, to extent protection and indeed privileges to Africans ${ }^{31}$.

To get at some of the issues raised above, it may be helpful to look at the relationship of the public sector to the private sector. How far is the public sector in a subordinate position; how far are the modes of operation, remuneration, etc., defined by the private sector, for the public sector; what are the terms on which the public sector competes with the private sector. The contradictory nature of public enterprise in the Kenya type of political economy is well brought out by Leys in part through examining its relationship with the private sector. The conditions of equality between the two sectors in Ghana during Nkrumah's time ("the co-existence of the two sectors") gives some idea of how public enterprise was conceived. The changing relation between the two sectors in Tanzania, towards the superior position of public sector and its role in defining the modes of operation, is instructive and provides an indication of the trends. It is also important to look at the magnitude of resources allocated through the public sector. The small amounts that are chanelled through the public sector in Kenya and yet its importance at certain levels of Kenya society and economy are both revealing. In fact it is only a handful of countries which allocate other than a marginal role for the public sector, even though the resources that are allocated may be of considerable political significance ${ }^{31 a}$. It would pay to give some attention to the personnel of the public sector, and to examine the membership of the boards. It will be argued below that some attention needs to be paid to the decision making process. The role that is found for the workers may be revealing, as well as the exact nature and extent of political as opposed to bureaucratic direction giving or of less overt interference.

The notion of economic power as outlined above both highlights the importance of political and general controls over and accountability of the public sector, as well as indicating directions in which control and accountability may most promisingly be sought. In the common law system, control over public enterprises is ultimately sought through control over the government. Political parties play little direct role. In the developing countries where there are dominating oneparty systems, a major problem may be the establishment of political as opposed to bureaucratic controls over the public enterprise. Another problem is the control over the government itself, an aspect which tends to get neglected in the literature, but which assumes a major importance in our analysis of the state one reason why control over public enterprise is weak is that control over governments

31 See Nowrojee, op. cit. For an account of the structure of state institutions for help to European farmers in colonial Kenya, see Ghai und McAuslan, Public Law and Political Change in Kenya, 1971, chap. III.

31a For an attempt to compare the size of the public and private sectors in Africa, see Charles Frank, "Public and Private Enterprise in Africa", in G. Ranis (ed.), Government and Economic Development, 1971. 
is weak. The political and economic factors suggest that the search for control is no simple matter, as is sometimes perhaps assumed by lawyers. We need to pay more attention to the decision making process, and we need to know more about the groups who share power and make decisions. In particular, worker participation issues have to be seen in the context of sharing power and enhancing enterprise accountability, rather than in terms merely of good industrial relations. How far worker participation does perform this function depends on the political consciousness of the worker.

The issues raised in this section cannot of course be adequately examined in the purely national framework. They need also to be seen in a wider context taking external and international factors into account.

\section{International Capital, Public Enterprise and the Domestic Economy}

It is clear that in Africa few economic activities can be divorced from the international capitalist system. Therefore the relationship between it and public enterprise, and through that, the impact on domestic economy must be one of the central themes of research. Much of the discussion on this point has centred on the question of management contracts, which are important, but perhaps not the most significant factor in the relationship. It is necessary to draw up a fuller profile - the impact of international and western financial institutions on the establishment and choice of public enterprise forms (e.g., for various reasons the World Bank may prefer to give loans to an autonomous public agency rather than the government as such; it may bring pressure on government to enter into particular transactions with the multinational corporations, as in the Volta River project in Ghana; terms of tied aid may force collaboration of the domestic multinational corporations on the developing country). It would be fruitful to examine the use of public enterprise form during the colonial period, especially since the second World War (particularly for the extraction of raw materials from the colonies). The analysis of the equity structure, control and management of public enterprises would help to indicate the role of private capital, and enable one to test the hypothesis mentioned earlier that where as in Europe the form of state intervention in the economy through private sector institutions helps to hide the extent of state participation, in Africa the converse is true, i.e., the use of public forms hides the extent or influence of private capital, although of course public enterprise may not have been set up as a camouflage.

The role of public enterprise in mediating between foreign capital and the local economy is important in significant part because there is now widespread feeling that international capitalism has been responsible for the underdevelopment of the Third World countries, and continued association with it on the part of these countries will merely perpetuate and entrench their dependency and underdevelopment ${ }^{32}$. Even those who consider that foreign capital can deliver useful assets, recognise that these assets would not be automatically delivered; the host country has to be vigilant and negotiate with care. It is argued that a key

32 For the growing literature on the subject, see A. G. Frank, "The Development of Underdevelopment", in his Latin America: Underdevelopment or Revolution, 1969; Walter Rodney, How Europe Underdeveloped Africa, 1972; Brett, op. cit. 
to the understanding of the phenomenon of public enterprise (at least in the African context) is its relationship with the foreign capital ${ }^{33}$. The West has a continued need for investments in Africa, to procure raw materials, to find markets, and generally to ameliorate the contradictions of the western capitalist system $^{34}$. On the other hand, the ruling elites of the developing countries perceive for one or another reason, that foreign investments are important for the development of their economies. So in the 1960s, under promptings from the World Bank and such institutions, most countries adopted codes of investment protection legislation, to attract foreign capital. While other legislation purported to provide some control over such investments, the general effect was to give a fairly free hand to foreign capital. Due to rising economic nationalism, the interests of the elites, the need for greater control over the economy, the shrewdness of the foreign capitalists, the mode of foreign investment changed from sole and direct investment to various forms of participation with local groups, prominently state institutions. The local elites were able to present an image of radical posture and policies by extending the public sector while foreign capital obtained more security, more favourable application of controls legislation, better access to local markets and finance, and a better public image. It is argued that while the modes of investment may thus have changed through the emergence of public enterprise, the reality has not, since the foreign interests continue to drain off the surplus in equal if not greater proportion; and often without the previous investment risks. Indeed, one can go further and say in that in so far the development of technology and the nature of the organisation of the MNCS now push them towards sale of technology and licenses, and occasionally consultancies, public enterprise provides an ideal form for their new activities, since in many countries there are few private groups with whom the MNCS could collaborate on this basis ${ }^{35}$.

We explored the nature and interests of the local elites in the previous section, but here we notice that it does seem that public enterprise is well suited to marry their interests with those of foreign capital. (In some cases of course the MNCS may wish to operate on their own, and at other times the initiative for partnership, which often means the sale of part of an established MNC's equity to the government, comes from the government. As Leys says in his study of Kenya, "When foreign investors were confident of the profitability of new investment within the level of protection offered them, they often tended to prefer to do without government participation. When, however, they foresaw that further protection would be needed, or that whoever first obtained government participation in a still competitive field would tend to get special protection at the expense of the rest, they were eager to secure government participation.” p. 133). Growing literature on management contracts, which constitute one of the main links between public enterprise and foreign enterprises, shows ways in which public enterprise, wittingly or otherwise, serves the interests of the latter ${ }^{36}$.

33 See, e.g., Botchwey, op. cit., Shivji. “Capitalism Unlimited ...”, op. cit.

34 Samir Amin, in Widstrand, Multinational Firms op. cit., Jalee, Pillage of the Third World, 1968 and Imperialism in Seventies.

35 See Green in Widstrand, op. cit., for the point that many MNCS are moving away from direct physical investment.

36 See Shivji, "Capitalism Unlimited ... “, op. cit., Sawyerr, op. cit., Coulson, "Blood Sucking Contracts". mimeo., 1972, and "The Fertiliser Factory", Maji Maji, no. 8 (1972), p. 26; Simonin, "Nationalisations and Management in Zambia”, Maji Maji no. 1 (1971), p. 23. For an earlier study of foreign investment in India, see Kidron, Foreign Investments in India, 1965. 
It is, however, necessary to consider seriously the hypothesis that public enterprise is established to promote greater national autonomy and to moderate the ill effects of international capital. In Tanzania in 1967 the expansion of the public sector was inspired by such considerations. It is necessary to examine a) how far such aggregation of state resources does succeed in this purpose; and b) if it does not, why not. How do public enterprises which are set up for broad national goals get co-opted by international capitalism? What does it tell us about the nature of the institutions of public enterprises, their modes of management, etc. A historical perspective here may be important. When Tanzania and Zambia undertook their first important nationalisations in 1967 and 1969 respectively, it was, and so regarded, as a bold step, and potentially important on the road towards national autonomy. Subsequent experience showed that expectations from equity control were unrealistically high, due to continuing dependency on foreign technology and management skills, but also bad netotiations leading to the completing of the nationalisation measures. But the situation has not rested there, and each country has taken steps to re-negotiate old agreements, improve its own managerial capacity, and move towards a better overall planning process. Nor is it always necessary that there is a basic incompatibility in the interests of the foreign investors and the host country, at least in the short run. On the assumption that total disengagement from the west is an unlikely probability, public sector/private sector joint ventures may well provide a starting point for developing countries anxious to acquire new technological and managerial skills, as well as some measure of control over foreign investors ${ }^{37}$.

The writing on managements contracts, while it makes a foreceful point, needs to be supplemented by a consideration of the dynamics of the situation. It is necessary to isolate a) poor expertise, negotiating skills and experience; b) the weak bargaining position of the developing countries; c) the corruption of local elites; d) technology dependence, etc., as factors explaining the deficiencies of such contracts. But it is unrealistic to assume that a developing country must remain helpless in the face of such difficulties. Given suitable social formations, the will and expertise, improvements can be affected. The question remains whether there are limits to such improvements. One needs to consider alternatives: is the importation of foreign skills, technology, capital likely to be on more favourable terms if this is done purely through the medium of the private sector? Is state leverage more effectively deployed through direct negotiations (i.e., public enterprise) than the regulatory mechanism (e.g., the general legal regime for the foreign investments)? More broadly, it is necessary to examine how many ills of public enterprises can be blamed on international capital. Mismanagement, certain forms of corruption, and lack of co-ordination may arise from causes quite independent of foreign capital, and if any progress is to be made in dealing with these deficiencies, they ought to be recognised as such.

The criticism of the role of foreign capital assumes that in various ways its interests are in conflict with those of the developing country. It is difficult to talk of the interests of the developing country as a whole, for different groups in that country

37 If a coherent long term strategy is devised, joint ventures can play a useful role in the transitional period. See the Andean Pact strategy on the eventual dissolution of joint ventures in favour of fully owned local enterprises. 
may have different interests ${ }^{38}$. As indeed is implied in the critique of foreign capital, its interests coincide all too comfortably with the interests of the dominant local elites. The criticism is therefore not that public enterprise is not successful, but that it is too successful. The real point of attack is thus the policies deliberately pursued through the public sector. Leys has shown how the Kenya elite is motivated by clear notions of the development of that country as a "periphery centre", or as sort of submetropolitan centre. Such a strategy obviously requires collaboration with international capital, in which collaboration public enterprise plays an important though not exclusive role. The interaction between local elites and foreign interests goes a long way to explain the nature of public enterprise.

While much of the attack on the international capitalist connections of public enterprise in developing countries is justified, there is however, a danger of overdoing the argument. In many countries in Asia and Latin America foreign participation is not the rule, while public enterprise has no better record than in Africa. Some studies of Nigeria and Ghana have argued that in fact the more successful of the public enterprises in these countries have been those involving foreign partners ${ }^{38 a}$. But more seriously, the attribution of the fault to foreign partners detracts attention from many internal problems. Inquiries into the performance of public enterprise in various countries show a record of inefficiency, corruption and maladministration. There is often a lack of sense of responsibility among the officials of public enterprises. Public corporations have not functioned as a form to draw persons with industrial and business expertise into the management of state enterprises; political leaders or civil servants have been the key officials, and have lacked the necessary management skills. If the management and negotiating skills could be improved, both the internal and external defects could be ameliorated. One tends to talk of foreign capital as if it were an undifferentiated category, but clearly there is room for competition among various foreign companies. Attention needs to be focussed on the precise mechanism and terms whereby the developing countries are exploited and attempts made to improve the balance in the favour of he latter.

\section{Public Enterprise, Law and the Plan}

At one, general level, the justification for public enterprise in Africa is that the governments must actively promote development, move from the "law and order" approach to a mobilisation and development one. It must therefore plan economic development. Most developing countries engage in some form of economic planning, have special ministries for the purpose, and produce five or three year plans. Public enterprises is one of the key instruments to promote and manage

38 This does not mean that one is not justified in choosing certain goals as desirable and using them as criteria for a critique of existing policies. Indeed it is in large part due to this approach that the true nature of public enterprise has been exposed. But an examination of public enterprises in a country with capitalist orientation does not tell us the limits of the socialist potential of public enterprises.

38a This is for example argued in Frank, op. cit., and Gerald Helleiner, Peasant Agriculture, Government and Economic Growth in Nigeria, 1966, p. 261. The argument is that the private partner is interested in profits, and therefore concerned about efficiency. It should be pointed out, however, that a great deal may depend on the precise formula for the division of profits between the government and the private partner, as well as other fees, etc. due to the latter. If the private partner is responsible for purchase of equipment, provision of management services, etc., it may seek to maximise its profits through exorbitant charges on these rather than through increase in the profits of the enterprise. 
change. The relationship of public enterprises to the plan and the planning process becomes a matter of particular significance. For one, it throws some light on the seriousness of the process and plan, for public enterprise is one of the few directly operating agencies of the government, and if its activities bear no relationship to the plan, this is good evidence that the planning process is not a serious exercise. For another, the specificity in the plan in relation to public enterprises will tell us about the nature of planning and its scope: whether it is "imperative" or "indicative", whether it is partial or comprehensive, the mix between private and public sectors, etc.

It is probably true to say that in few countries is planning a realistic exercise, i. e., one which actually determines how its scarce resources are allocated, investments made, pricing and dividens policies, etc. Nor is it likely that any targets, quantitative or qualitative, are set by the plan for public enterprises. In few countries are the enterprises themselves consulted about the plans which they are supposed to implement ${ }^{39}$. A study of planning in Africa would be useful to establish some points about the role of public enterprise in the national economy. It is now argued that planning does not mean setting of targets, but a process, in which the resources available are examined and their use determined in relation to priorities, that errors are spotted and remedial measures taken, and that it is essentially a continuous exercise in projection, evaluation, and correction ${ }^{40}$.

Apart from the general issues mentioned, how far the plan deals with and provides the agenda for public enterprise is important in its implication for law. Can it for example be argued that as the planning process becomes well established, as there is more centralisation of decision-making, and as more technical economic and financial criteria are employed in resource allocation, there is inevitably a shift in power and influence away from courts and quasi-judicial tribunals, and lawyers, to technocrats? Advising private or public clients becomes less important than making a case to the bureaucrats (although it is possible to underestimate the importance of skills of negotiations by lawyers in the private sector economies). It is also likely that if the planning process is taken seriously, many of the controls over public enterprises would come less through general standards set out in legislation or regulations, than the budgetary and financial processes, especially in so far as finance is likely to be a scarce resource. As the plan process becomes effective, is the autonomy of the public enterprises reduced?

The relationship between law and the plan can be examined at another level. The imperative of the plan is often an argument for vesting descretionary powers in public authorities and officials. While the plan may call for discretion, how far does it structure the exercise of the descretion? In so far as the law is silent on the criteria whereby the discretion is to be exercised, how far does the plan provide guidance? If both the plan and the law are silent, how far are alternatives available, especially a national or ruling party ideology? The role of ideology in fashioning and structuring discretion is a much neglected topic. In so far as public enterprise is usually justified in terms of general policies and indeed of

39 An ECA conference on the Role of Public Enterprises in Planning and Plan Implementation (E/CN. 14/463) (1969) concluded that planning agencies fail to conduct feasibility studies and fail to consult enterprises about projects they were to implement, para. 14.

$40 \mathrm{It}$ is unnecessary to refer to the vast literature on planning. For the discussion of planning as a process, see Hellenier, "Planning in the Sixties" Journal of Modern African Studies. For a view that "five year plan" planning should be abandoned, see Waide, "Planning and Annual Planning as an Administrative Process", in Planning in Tanzania ed. A. H. Rweymamu and B. U. Mwansasu, 1974. 
ideologies, one would expect that ideologies would provide guidelines to the exercise of discretion. It may be that in the early stages, when appropriate modes of operation are being worked out, legislation cannot be counted on to provide the standards, and there has to be a reliance on the general aims in ideology and the plan ${ }^{41}$. Indeed, in so far as the general aims of an enterprise are concerned, legislation may be of little help, since the tasks of the enterprise are set out in broad terms. (A frequent criticism by lawyers and others of public enterprise legislation is that it is not specific on the functions of the enterprise $)^{42}$. Sometimes an enterprise is given too many things to do, some of which may seem to be in conflict. Goal articulation becomes an important matter. What is the relationship among law, ideology and the plan in this regard? What are the modes for the articulation of goals and the reconciliation among apparently conflicting goals?

How does the law go about translating the plan? Here a great deal depends on the nature and functions of the plan. At one extreme we have the Soviet kind of central planning where the plan is comprehensive, sets out firm production targets for the different enterprises, and is binding on the enterprises. It thus enjoys the status of legislation, indeed of superlegislation. In some senses the implementation of the plan takes precedence over other legislation and legal rights, so that most transactions, contracts and liabilities are interpreted subject to the needs of plan fulfilment. The dominant status of the plan in law has given rise to various features of socialist legal systems: the arbitration of disputes between public enterprises by special tribunals; the emergence of the mandatory contract; the emphasis on specific performance as a remedy for breach of contract; division of property into various forms of ownership; the punishment of certain kinds of conduct through criminal rather than the civil process ${ }^{43}$.

In African countries, the plan does not enjoy the status of law (although this does not necessarily mean that they are not influential or indeed decisive; the lack of legal standing may be more a reflection of the low status accorded to legislation or the legal process). Few plans explicitly address themselves to problems of institutional development and implementation of its policies. This is only in part a result of the fact that the plans are indicative. More seriously, it may reflect the dominance of economists in the planning process, with their notorious neglect of institutional features of development. This does not mean that the plan does not have an impact on law, for various new institutions may be established, new laws enacted, e.g., to attract foreign investment, regulate the location of industry, control prices and wages, etc. But these do not grow directly out of the plan, as it were, and their implementation and interpretation are not necessarily controlled by the plan.

In spite of the absence of a direct relationship of this kind between the plan and the law, one may hypothesise that certain implications for public enterprise and its law follow from the planning process. It has already been suggested that the plan may lead to a diminution of the autonomy of the enterprises. It may also be stated that while public enterprise is said to follow from the needs of the plan,

41 For a preliminary discussion of the relationship between law and ideology, see Ghai, "Notes Towards a Theory of Law and Ideology: Tanzanian Perspectives", Vol. XI (no. 2) East African Law Journal (1975).

42 See for example the report of the Asian Colloquim on Public Corporations (held in Colombo, 1974), forthcoming; see footnote 12.

43 For a good account of the plan and its status in and impact on the law, see K. Katzarov, Theory of Nationalisation, 1964, Section IV. Katzarov deals with the system before the economic changes in socialist countries. For a recent account see Eörsi and Harmathy, op. cit. (footnote 7) and Sarkozy, "The Legal Status of State Enterprises in the Socialist Countries, in particular Hungary", 1975, mimeo. 
that it is in fact the proliferation of public enterprises (whose establishment is of ten not related to the plan) that gives greater urgency, relevance, and possibly coherence to the planning process ${ }^{44}$. Certain it is that in the absence of a substantial public sector, the plan can seldom go beyond exhortation. The existence of a substantial sector creates the need to determine priorities and to allocate resources according to some rational plan. This process in turn has a major impact on the law. As the law responds, even in an ad boc fashion, to the needs and problems of an emerging public sector, particular patterns begin to emerge, which become defined if the public sector maintains its position in the political economy of the country. Some of these trends will be touched on in the following sections.

\section{Form and Structure}

Much of the debate among lawyers on structure has centered on the relative merits of different organisational forms, principally the government department, the public corporation, and the company. Even though the earliest form of public enterprise was in most countries the departmental form, there now appears to be a consensus that it is not a very appropriate form. The case against the department form is that it is too bureaucratic, prone to delay, has rigid financial regulations, and does not provide room for commercial initiatives that seem necessary in a business enterprise. Sometimes, particularly in Latin America, the the case against the department is that it is part of the structure of administration which is corrupt and incompetent, and that it is necessary to set up new independent institutions which would be free from that machine. While the textbook case against the department form, and the case for more flexible, and autonomous institutions, is well-known, it is not obvious how the different forms actually operate and what the practical significance of the differences are. Certainly many of the strictures against the department form are not justified. It is possible to have separate budgets, extensive delegations of power and authority are possible, etc. To a large extent the textbook case is based on the European economies where the basic system is will established and few people want public enterprise to introduce any qualitative change. Autonomous institutions, conforming largely to the modes of the private sector, but redressing the weaknesses of the market mechanism without challenging it, seem well suited. But the major objective of public enterprise in the developing countries, whether informed by socialist or capitalist aspirations, is not to make minor adjustments to the system; the overwhelming case for public enterprise is to transform the system. Given the odds which public enterprise must work against in these circumstances, it is important that it be strongly backed by the government. Equally, since public enterprise is regarded as a key instrument of government policy, its autonomy has little constitutional or economic justification. The case for autonomy has to be based on considerations of efficiency and responsiveness to policy. A heavy price may be paid for the distance between the government and the enterprise. The

44 For studies of the relationship between the plan and the public sector in Tanzania, see Loxley,
"Financial Planning and Control in Tanzania", and Packard, "Management and Control of Parastatal Organisations", both in Towards Socialist Planning, ed. by Uchumi Editorial Board, 1972. 
adoption of formal autonomous institutions leads to ad hoc interventions, increasingly blurred lines of responsibility and thus to the evasion of responsibility.

The debate about the relative merits of the corporation and the company forms is likewise beclouded by a priori assumptions. Thus it is assumed that public corporations are more responsive to the broader governmental machinery, ensure a better accountability of the institution, are easier to operate since they are forms for public enterprise, while. such use of the company is regarded as somehow improper, since the company belongs to the private sector. It is only if the government intervention is that of a joint venture with the private sector that it may use the company form. There may be no neat distinctions: public corporations often carry out their functions by establishing fully or partly owned companies, while the companies' code sometimes applies to public corporations ${ }^{45}$. It is in fact, as Hanson has said, extremely difficult to come to any conclusions on the relative merits of different forms. "Practically every known type of public enterprise is to be found working well in some circumstances and badly in others, and it is extremely difficult to say to what extent the performance of a particular enterprise has been affected by the form that the political authorities have given it, as to isolate this factor from all the others is usually impossible ${ }^{46}$." Nor is it easy to identify the criteria for the choice of form, and quite often the form seems to be an accident of history (although in some countries careful consideration has been given to form, as in India where the company form is preferred).

The debate is sometimes rephrased in broader terms of the relevance of form. A study of public enterprise in Ghana sought to answer the question whether Ghana's use of the public corporation form had been responsible for the poor record in the public sector. The author's conclusion is that the form contributed in some measure to the failure, but also that the adoption of the form by Ghana led to waste of legal and administrative resources ${ }^{47}$. Another point of view is that the form is irrelevant. Karl Renner, for example, has argued that the form of association is "merely an empty legal frame4", and can be used for different purposes. His editor, Kahn-Freund disagrees, and considered that the form was important and relevant, for it gave a qualitatively different character to the assets ("large numbers of shifting morsels of capital", p. 225) that were consolidated within the framework of the form.

The debate is tied to the wider, and more important, question of the impact of form (or "superstructure") on the content or the base. The question arises in different contexts: is it possible to bring about fundamental changes in society

\footnotetext{
45 See R. Turkson, “Does the Companies Act apply to Public Corporations?”, University of Ghana Law Review See also the discussion on this question in Katende, Chesterman, Thomas and Mann, “The Law of Business Organisations in Eastern and Central Africa", forthcoming, chap. XIV, esp. as regards the position of the Uganda Development Corporation.

46 Hanson, op. cit., p. 337.

47 Pozen, op. cit. It is probable that Pozen exaggerates the influence of the form, and he certainly underplays the significance of the economic factors. He also suggests that notions like the importance of the legal structure of public enterprise are responsible for drawing talented students to law away from other more useful subjects. The recruitment to the legal profession, however, is more likely to be from other more useful subjects. The recruitment to the legal profession, however, is more likely to be
determined by the market forces and the rates of compensation. The question of the legal structure of enterprises is a matter of concern largely to the "public sector" of the legal profession, which has always had difficulty attracting lawyers, as opposed to a rather large private practising bar. See a forthcoming study of the Ghanian legal profession by Robin Luckham.
}

48 Karl Renner, The Institutions of Private Law and their Social Functions, 1949, page 217. 
through law and institutional forms; how far can a society committed to socialist development continue to operate through economic institutions of the colonial or previously capitalist society. Underlying much of the debate among lawyers and public administrators on structure of public enterprise is the assumption that the form is crucial, and a UN conference on public enterprise (1954) went on record that "the single most critical control point is the law, decree or other basic authority providing for the creation, of public enterprise. This is likely to determine in large measure all other organisational relationships ${ }^{49}$." At a subsequent UN conference (1966) it was concluded that the alleged decisive influence of the law regulating the public enterprise ... "has proved illusory", and "that there is indeed no discoverable correlation between the legal rights and obligations of a public enterprise and the quality of the performance which it achieves ${ }^{50}$."

It is inherent in the nature of the mode of debate that conclusive or even tentative answers are not possible. That there is some sort of relationship between form and substance is undeniable, but it is more difficult to explicate the dimensions and details of the relationship. The form is not merely an empty shell; it is a device for an aggregation of resources; creation of bureaucracies; the pursuit of goals and a vehicle for entering into relationships with other groups. In time the form can define and elucidate the underlying problems, if only by discovering its own limitations. The dialectics between form and substance need to be studied carefully. In one sense much of social engineering through law proceeds on the assumption that forms, backed by state power, can change the economic base. Is of ten the form so far removed from the underlying reality that it has no impact on change? What is the minimum fit between form and substance necessary to set some interaction in motion? A historical dimension may be helpful here. Public enterprises are subject to different pressures and constraints, and perform different functions at different stages of the growth of a country, and it is unhelpful to suppose that the same form, and the same set of relationships, should persist through all periods. Control may be more important in the early stages of an enterprise, while greater autonomy may be required once the contours of policy and programme are clear. It is also possible that institutions which begin with considerable autonomy are brought under increasing control over time, not only of course for economic reasons. As Green has suggested, a series of studies of firms/enterprises exploring key issues through over time can provide a useful basis for the analysis of form in relation to its appropriateness for different activities, e.g., banking, commerce, transport, agriculture, manufacturing; and the degree of consistency at time and over time, and the nature of change over time ${ }^{51}$. The National Development Corporation (N. D. C.) of Tanzania provides a good case study. Its forms and to some extent functions have been changing over a ten year period. It started in 1964 as a standard joint venture investment institution, with a wide cluster of functions, promoting investments as well as entrepreneurship, as well as a holding company. In the absence of other industrial

49 Some Problems in the Organisation and administration of public enterprises in the industrial field,

50 Report of the United Nations Seminar on the Organisation and Administration of Public Enterprises, 1967 , p. 9.

51 Green, "Historical, Decision Taking and Firm Dimensions", notes at the workshop on public enterprise, Accra, 1975. The following account of the National Development Corporation draws in large on from these notes. 
corporations, and in the absence of an operating planning mechanism, the NDC became a primary instrument of government policy, in formulation and execution, and this fact was recognised and underscored by having 7 key economic ministers on its board. It received 7 of 12 largest manufacturing companies in 1967 after the Arusha Declaration nationalisations, and its own previous investments began to mature. It was now required to have a majority interest in joint ventures. It functioned during $1967-70$ as a vague large scale company promotion centre, but with unequal planning and management for subsidiaries. Chaotic relations resulted because of overlap of several sector ministries in the activities of the NDC. The size of and power concentration in the NDC produced anger, and there was political disquiet at the degree of the lack of its responsiveness to state policies. The period 1971-74 saw the spin off of all non-manufacturing units to separate central management and planning corporations, e.g., hotels, wood products, mining, as well as spin off of industrial areas which were large enough to justify it, e. g., textiles group. Its board was reconstituted to bring it in line with other corporations, consisting largely of civil servants from the relevant ministries, and to play down the ministerial dominance. It was brought under a single sectoral ministry, and tighter central parastatal control. The process came to a head in 1974 when the top management was shifted out, and one of its civil service critics was appointed as the General Manager (following the appointment in 1972 of one of its main political critics as the parent minister). It is clear that form and substance were closely interlinked in this process. At first the form was not very clearly thought out because the functions were not, while the broad framework of the form facilitated the expansion of the scope and activities of the corporation. This expansion in turn led to the reorganisation of form, especially with extensive ministerial representation, which recognised and emphasised the pre-eminence of the corporation. New political developments in 1967 and the greater attention to the planning process within the governmental structure highlighted the size and strength of the NDC, and led to further reorganisation, this time in the direction of limited functions, both in terms of policy and jurisdiction. The decentralisation measures highlighted the unprofitable enterprises of the corporation, which had been cushioned and supported by its more profitable mining enterprises, which in turn led to more stringent procedures for future investments ${ }^{52}$.

Another method whereby one can get to grips with the question of structure is to focus on the decision making process. This approach is useful both to elaborate and highlight the concepts and reality of autonomy and control, and to demonstrate by what group and in whose interests decisions are made. Our attention is directed to the ways in which the government intervenes, and the kinds of decisions and matters in which it intervenes. It throws some light on the questions of centralisation and decentralisation, both in the relationship of the enterprise

\footnotetext{
52 Some perspectives on form and substance may be gleaned from the study of the development of the company in the common law of England. Here to a large extent the development of the economic forces required particular forms, especially of incorporation and limited liability. The forms, however, were not immediately forthcoming, and various devices were used to get round the problems arising from their absence, some of which devices still remain in use, although better alternatives are now available. Eventually, however, the force of economic factors led to the establishment of the general principles of incorporation and limited liability. The force of the economic factors is also seen in the fact that it is now accepted that in the fast changing economy and its organisation, regular periodic fact that it is now accepted that in the fast changing economy and its organisation, regular periodic developing countries is that in the latter case, the form has emerged before the economic factors relevant to it have crystallised. For a brief account of the development of the company law in England, see LGB Gower, The Principles of Modern Company Law, 3rd ed., 1969).
} 
with outside agencies, and in its internal organisation, especially the reality of worker participation. It can help to draw a fuller profile of the hierachies of authorities concerned with public enterprise. The legislation on public enterprise generally defines only the relationship between the enterprise and the government, but tells us little about how the government organises itself to guide and control the public secter, e.g., the role of the minister, the role of the Cabinet, and the coordinantion of the public sector. Nor does the legislation often spell out the relationship between the Board (especially its chairman) and management, a source of much confusion, inefficiency and resentment. An examination of the decision making process would get us into these areas. It can also help to categorise enterprises by reference to the degree of centralisation or autonomy (e. g., highly centralised, completely decentralised, and postions in between), and thus to test hypothesis about the relationship of centralisation or degree of autonomy to the degree of accountability and efficiency. A historical dimension tied in the decision making approach would help to test what one might state as hypothesis: that it is inevitable that the autonomy of public enterprises get eroded over time; that the larger the public sector area, the smaller the degree of its autonomy. A careful analysis of the motives behind decisions and the lack of articulated criteria might help us to understand under what political and economic conditions autonomy gets eroded.

Decision making has to be more broadly defined than how actually a decision is made. Svendsen in his study of decision making in the NDC in Tanzania says, "Decision-making inside the organisation cannot be analysed in isolation from the general framework in which the particular organisation operates. It is also useful to understand that "decision-making" covers all the functions of the organisation, i.e., not only those measures which are presented for decision, but also the functions based on past decision, or on customary behaviour. Now and then very important decisions affecting the future operation happen to be made by the decision makers in an indirect way so that it is only later (if ever) realised that a "decision" was made at that and that time in such and such a way.

"To arrange thinking on decision-making in a particular organisation the following major elements of the process may be separated:

1. the content of the decisions, i.e., the objectives of the organisation;

2. the criteria on which to base the decisions;

3. the structure of the decision-making, i.e., the internal procedures in the organisation and its relationship with other organisations;

4. the capacity of the organisation and the other organisations with which it is related, i.e., mainly questions of staffing ${ }^{53}$."

Using this approach, Svendsen examines the relationship between the corporation and the government, between the board and management of the corporation, between the corporation and its subsidiaries. Apart from the formal legal provisions, he concludes that the factors which determine who in fact exercise power depends on the availability of information, the availability of time to analyse the information, the staff and planning capacity of the institutions, the need and availability of financial resources. During the period under study, (1964-68), many

53 K. E. Svendsen, "Decision Making in the NDC", reprinted in Cliffe and Saul, Socialism in Tanzania, vol. 2, 1973, pp. 89-96. 
of these factors favoured the corporation, and thus it achieved a high degree of autonomy. Only if such profiles are drawn, both in relation to key decisions and over time, it is possible to get some idea of the significance of structure and form, and more especially control and autonomy.

\section{Public Enterprise and the Legal System}

The focus in legal scholarship on form and structure has obscured the larger impact of public enterprise on the legal system ${ }^{54}$. The problem may be that we have started with a particular theory of the public corporation and have been overconcerned to see if the theory is working or workable. As was suggested earlier in the paper, public enterprise (on the present scale) is essentially a new institution with its own demands on the legal system, and from the legal system, and in the process a number of solutions are proposed and decisions made. What is the cumulative effect of these? One way to get at this enquiry may be to proceed with the state of the law before public enterprise emerges as a significant factor, which is to say, largely the French or English based law. Unlike socialist legal systems, the common law or traditional civil law does not start with a clear theory of public ownership of the means of production and of its management ${ }^{55}$. Some of the central concepts and institutions of socialist legal systems are based on a publicly owned and managed economy, and so are able to accommodate public enterprise in a systematic and coherent way. This can scarcely be said of the common law, which has a heavy private enterprise bias. The major institution for commercial and industrial activities is the company, the rules for which have been developed on the premise that the essential responsibility of the management is to maximise profits, and while various rules have evolved to protect the public interest, there is a basic reluctance to interfer with the internal affairs of the company. The management thus has very considerable autonomy.

The rules of contract and tortious and corporate liability were to a large extent determined by the needs of the private sector and the company form, although there have been some problems in adapting the criminal law to the company. In so far as the common law recognised alternative forms of commercial or business organisation, it was the public corporation (with a lesser role for partnerships and co-operatives). While the power to establish corporations is a prerogative power, and was used from Tudor days onwards, the common law developed relatively few rules to deal with them. The public corporation in its present form is a device of recent times, and derived largely from legislative activity. While in its structural characteristics it owes much to the company analogy, autonomy achieved through a board of directors, courts have played a relatively minor role in their regulation. Legislative and administrative controls have been considered more important, although the two do not necessarily work towards the same ends. It is perhaps the relative paucity of common law rules to deal with administrative behaviour as well

\footnotetext{
54 For a good general survey of the legal issues around public enterprise, see W. Friedmann, “Public Enterprises", in International Encyclopedia of Comparative Law, 1974.

$55 \mathrm{It}$ is often hostile, at least to begin with. Cf. the provision in French law (of 1791) which has been interpreted to mean that the State and local governments may not create business enterprises the existence of which would result in a distortion of market equality. See $R$. Drago's chapter in W. Friedmann, Public Enterprise in Mixed Economies, op. cit.
} 
as controversy about the proper role of public enterprise that explains the absence of reliance on a model of rules and dependence on discretion and ad hoc directives. But in so far as public enterprise occupied a small place in a largely private enterprise economy, it was not surprising that the courts applied rules by analogy from that sector, in instances when their jurisdiction was exercised ${ }^{55 a}$.

Another aspect of the common law that is relevant here is its attitude towards administrative discretion. The common law is biased against administrative discretion. This is not surprising, since administrative discretion is seen as a threat to lawyers, and it is lawyers who formulated the rules of the common law. In the late nineteenth and the early twentieth century, the courts were hostile to administrative discretion, as vested in licensing, housing, town planning authorities, etc., and tried to frustrate schemes for social and economic reform which depended on the exercise of discretion. But since the legal sovereignty of Parliament in Britain is basic, it was possible by legislative means to curb the intervention of the courts. While the courts tried to get round the rules excluding their jurisdiction, it can be said that as a rule that the courts either intervene on a narrow set of grounds, the rules of natural justice, or stay well clear of administrative discretion. Unlike the US, where constitutional provisions have enabled the courts to formulate broad and specific rules to regulate administrative behaviour, African colonies inherited the narrow and limited rules to regulate administrative behaviour ${ }^{55 b}$ Since public enterprises are in many respects administrative authorities, and operate to a significant degree through discretionary powers, it might be expected that the courts would not take an active stance vis-a-vis them, and that gradual development of judge made rules in this area was unlikely.

It is worth noting some consequences which follow from this state of affairs. One, that the most developed form for business organisation comes from private enterprise, which gives considerable autonomy to management. Second, many of the detailed operating rules of the legal system, e.g., notions of property, contract, tort, adjudication, grew up around private enterprise. Third, the strong position of the common law and the courts, under the influence of Dicey's notion of the "rule of law" which argued against any special rules or institutions of dispute resolution, for public authorities, ensured that there was little specialised law to deal with quasi-business activities of public authorities, e.g., the relatively underdeveloped law of public contracts. Fourth, the device of a distinct legal personality for public enterprises, in itself a response (in part) to the inadequacies of administrative law (e. g., rather wide immunities from liability or litigation of governmental authorities) took them out of the regime of governmental authorities, without specifying clearly their submission to the regime of private authorities. The ambiguity between their private form and public functions (of the govern-

\footnotetext{
55a Patrick McAuslan has queried this formulation, and suggested an alternative hypothesis. "The analogy the courts used in developing rules about 'commercial'. public corporations was drawn from uncommercial public corporations, i. e. corporate local authorities. These were 'inferior' bodies to courts and could be controlled via certiorari etc. These in turn derived from notions which came into being when the central government-courts, Council, etc. - was extending its control over autonomous or would be

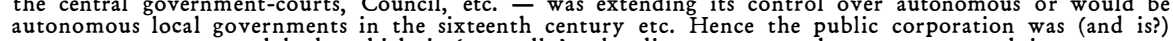
seen as a governmental body which is 'naturally' subordinate to central government and its courts it is not seen as an extension of government at all." (Private communication)

55b Since Ridge v. Baldwin (1964) A. C. 40, the English courts have extended the scope of judicial review over administrative discretion. The courts in many developing countries which inherited the common law still remain rather passive. Even in Britain, the courts have not become involved in many new areas of economic activity or planning. See generally, Sir Leslie Scarman, English Law - The New Dimensions, 1974.
} 
ment owned company) or their public form and commercial function (of the public corporation) was seldom resolved, leaving considerable doubts about the status of employees, application of protective legislation, e.g., rent restriction laws, tax liability, etc. ${ }^{56}$. It is not always apparent how the rules of liability, contractual capacity, etc., which were established to govern private sector entities should be extended to public enterprises or, on the other hand, how far rules to govern public institutions should be applied to public enterprises, when they have explicit commercial or industrial functions. What is regarded as the more appropriate analogy (which in turn would depend on the political economy of the country, but may also be significantly influenced by the inherited legal tradition) would determine various rules of their operation, the role of lawyers, the provision of legal legal services, dispute settlement, and thus the larger impact on the legal system. The legal theory of public enterprise is insufficient to solve the problems. In so far as there is a legal theory, it may be out of tune with the goals of or expectations form public enterprise. This is particularly likely to be the case in a radically oriented country encumbered by a legal system derived from the "metropolitan" country. The legal theory then, instead of solving problems, adds new ones. The political response might be either to device a new theory, with its attendant rules, tinker as best as one can with the old one, or try to operate without one. What course is adopted depends on a number of factors: the size of the public sector and its strategic importance, the participation of outside, especially foreign, agencies, the strength and skills of the legal profession, both within and without government, etc.

In so far as existing institutions, i.e., the corporation and the company are used, what happens to them? Do they undergo a qualitative change? Do they widen the gap between law and reality? Do they lead to the progressive disregard of the law? In Tanzania the government has used the company form extensively for public enterprise. At first the forms and rules of the private sector company influenced the government company, and only minor amendments such as those dispensing with more than one shareholder, general meetings, etc., were made. As more and more substantive amendments were made, e.g., powers to modify articles and memorandum, transfer assets, special procedure for winding up, etc., two streams of company law emerged, one dealing with private and the other with government companies. As the government companies tended to become more important, they began increasingly to constitute the norm by analogy with which private companies were regulated. Thus governmental powers over dividend policy, compulsory investment in specified securities, registration and winding up, over public sector companies were extended to private companies. The two streams are beginning to merge again, but the pattern is that of the government company. The developments in Tanzania are to be explained in terms of the size of the public sector as well as the government's attempt to control the economy. Other countries may prefer to let the public sector be regulated in large part by analogies with the private sector.

56 In one sense the lack of a formal division between public and private law in the common law has facilitated the accommodation of public enterprise, esp. since it is not necessary to worry about jurisdictional problems. See Friedmann, op. cit., (footnote 54). On the other hand, there have been difficulties in the common law based courts in Tanzania in bringing special rules of liability for public servants for corruption and some other criminal conduct to bear upon the employees of the public enterprises. See James and Ligunya, "Organisational relationships and the control of parastatals in Tanzania", in Vol. 5 Eastern Africa Law Review (1972), esp. pp. $41-43$. 
The manner in which disputes between public enterprises are resolved may be of some significance. By clothing them with legal personality and conferring full capacity, it is assumed that they are subject to the court's jurisdiction, as indeed they are. But it is unlikely that one public enterprise will sue another in court, unless the basis of the economy has altered dominantly in favour of the public sector. In practice disputes will be resolved in informal or bureaucratic ways. Apart from reducing the load on courts, and limiting the scope of courts to influence the development of legal doctrines in the relevant fields, the effect of informal dispute settlement may be to de-emphasise the importance of established legal concepts of liability and remedies and ultimately of negotiated agreements and the related documents. New criteria may emerge to determine the relationship between public enterprises, in which the plan may play a more important role than the existing rules of law and the mode of their interpretation. If on the other hand, the plan is not clear or authoritative the relative political strengths of the parties may become the decisive factor. The increasing government control of the activities of public enterprises may seriously qualify the exercise of full legal capacity, modify the concept of property, etc.

In this connection, it is worthwhile to look at the provision of legal services to the public sector. One way is to let the private legal sector service the public economic sector, with each public enterprise free to choose its own lawyers. Another is for them to employ their own lawyers, and rely on the private bar only for specialised services. Or public enterprises could be required to take all or part of their legal work to a government department, the office of the AttorneyGeneral, or a specialised public law agency, like the Legal Corporation in Tanzania. How the services are organised has an impact both on the organisation of legal profession as well as on the operation of the enterprises. In Kenya, for example, the public sector appears to have channelled its work to private African practitioners, thereby facilitating the emergence of an African legal profession in an otherwise tightly competitive field dominated by Asian and Euroean lawyers. The result has been paradoxical - to strengthen the private bar, but at the same time increase its dependence on the state. In Tanzania, on the other hand, the establishing of the Legal Corporation to which all legal work of public enterprises has to be referred, has resulted in gross reduction of business for the private bar, and has led to some form of socialisation of the legal profession. It has also forced a reconsideration of the question of the entire organisation of the legal profession, especially as the shrinking of the private bar also posed problems for the provision of defence counsel in criminal prosecutions. As for the effect on the enterprises, one may argue that when legal services are decentralised, whether through the private bar, or in the individual enterprises, legal advice and interpretation tend to favour the interests of the enterprise and to justify its plans, and thus central control becomes difficult. On the other hand, if the legal services are centralised in an institution which is subject to government control, the lawyers do not identify themselves so closely with individual enterprises, and show more fidelity to central policy directives and laws, thus facilitating control of the enterprises by central agencies. It is also posible that such an arrangement reinforces the image of the lawyer as a technician and reduces his role to putting into "legal shape" decisions which have already been made. It is questionable whether this does not ultimately reduce fidelity to law. 
This raises another point, the role of the legal system in public enterprise, especially during a period when rapid changes take place, institutional relationships are fluid, the optimum modes of operation have not become clear. An additional difficulty is that much of the inherited legal system is not responsive to an active and "pattern setting" public sector, many of its assumptions and rules being antithetical to direct state intervention in the economy. There are at the same time increasing pressure on the economy from domestic and international sources. The governments argue the need for maximum flexibility, and are intolerant of firm rules and standards, which bind them as well as other agencies. There is thus a trend towards broad discretionary powers to be granted to the government, both at the political and administrative levels. As wide discretion is vested in officials, there is less concern to define standards and criteria for its exercise, and therefore legislation is less and less of a guide to the exercise of power. The notion of law as a system of rules is under erosion. This is not to argue that discretion is necessarily bad. Firm and clear standards may not be possible in many situations, and if the economy is substantially in the public sector, may even be unnecessary. Some discretion is always needed, and part of the question is as to the proper division of it between the government and the enterprises, which is, to an extent, to restate the problem of enterprise autonomy. Another question is the generality and specification as between different legislative orders - parliamentary legislation, regulation, and rule books or manuals. While it is not necessary that Acts of Parliament carry a great deal of detail, some instruments ought to address themselves more specifically to modes of operation, so that the importance of process and procedure, and evaluation of data is emphasised, as well as that there is a clear allocation of responsibility for decision at various levels (and hence accountability).

The stress on the legal system comes from another factor, and it is potentially more significant. The growth of a state sector which is not accommodated within the legal system - for whatever reason - poses a grave threat to the relevance and indeed viability of the legal system generally. A number of factors which tend to make it difficult to operate through the legal system have been mentioned, and so long as these are temporary phases, the damage to the legal system may not be serious. But if the optimum or acceptable modes of operation which emerge after trial and error, are not institutionalised through the legal system ${ }^{56 a}$, there is the danger that law will enter a period of attrition. The damage will be not only to the legal system described as some kind of autonomous activity, but also to the state and public sector itself. The role of the legal system to consolidate changes through rules and institutions, and to act as a source of legitimacy for the exercise of state functions and power, may be jeopardised. Already, in the area of political and constitutional activity, the autonomy of the legal system has been eroded or

\footnotetext{
56a For such institutionalization is often possible. Although writing in a somewhat different context, Kenneth C. Davis' statement is apposite here. "Most new administrative subject matter, however, must at first be committed to discretion because no one is able to write rules or even meaningful must at first be committed to discretion because no one is able to write rules or even meaningful they naturally follow precedents, for they find it inefficient to rethink a question they have once resolved to their own satisfaction, in absence of special reason to do so. The precedents accordingly grow, the opinions are soon stating some standards or other guides, and the movement may

go on toward principles and, for some subjects, rules.
"This normal progression from unguided discretion to some use of precedents to clarification of standards to greater use of precedents to discovery of principles and finally to formulation of rules is a phenomenon of major importance." The quotation is from his Discretionary Justice, 1971, p. 108.
} 
abolished $^{57}$. We do not of course know enough about the effects of disregard of parts of the legal system on other parts or on the system as a whole, but if the legal system is not used in the management of political and economic life, it is somewhat doubtful if it can survive as a liable system to regulate other sectors of a community. Whether diminution of the role of the legal system is necessarily undesirable may be open to question ${ }^{58}$. If, however, the legal system is to be rehabilitated, more than political will is necessary. There needs to be a different emphasis in legal education on the skills to be developed in lawyers, and on the other hand, a general and wider acceptance that there is more to law than rules and technique ${ }^{59}$. But what more there is to law is not always clear, or at least is not above controversy. Even apart from neo-natural law adherents, it is often argued that the values of the law are reasoned decisions based on a careful assembling of facts and their evaluation, the absence of arbitrariness, the provision of standards and criteria so that there is predictability of action on the part of state and other authorities. Such an elaboration of legal values immediately highlights the dilemma for the legal system. In the attempt to maintain the relevance of the legal system, lawyers may seek to make law more instrumental, a technique to further the aims of economic decision-makers. In this task, they either provide for wide and rather unregulated discretion, or end up with a large number of ad hoc rules and institutions, unconnected by any general principles. They are thus forced into a compromise with what are regarded as the basic values of the $\mathrm{law}^{60}$. Whether the situation need be quite so paradoxical or contradictory and whether a blend of skills, imagination and commitment can provide a combination of relevance and legal values is a question which cannot be answered here. But that public enterprises raise the question in an increasingly acute form cannot be doubted.

\footnotetext{
57 I have elsewhere argued that it is more realistic to look at constitutions in Africa as means and instruments of political manipulation than as autonomous systems of normative rules and principles. See Ghai, "Constitutions and the Political Order in East Africa", Vol. 21 International and Comparative Law Quarterly (1972) p. 403-433.

58 This issue is discussed in Ghai, "Notes Towards ...", op. cit., footnote 41

59 On this point, see Legal Education in Changing World, 1975, and Law and Development 1974.

60 The point is put as fellows by Daintith, "Public law provides, at one and the same time, the framework for the Governmental task of economic management, and one of the instruments with which that task is carried on. Between these two roles, the framework role and the instrumentality role, a delicate balance must be kept. Frameworks imply restriction; if this role is neglected, and the framework becomes unduly flexible or shapless, then the values which the institution of the law itself protects freedom from arbitrariness, predictability of State action - may be jeopardised. If, on the other hand wo concentrate all our attention on these values, as Whigs like Dicey and neo-liberals like Hayek would have us do, then we may impair the capacity of the law to serve as an instrument of economic public policy and consequently hinder the achievement of our economic objectives", op. cit., p. 10. In many developing countries, the consequence in the second situation is not so much that economic objectives will be hindered, as that the law will be progressively disregarded and come under further contempt. For suggestions of a proper balance between the needs of planning and discretion and the values of law, see I. P. W. B. McAustan, "The Plan, The Planners and the Lawyers“, Public Law, 1971, pp. $247-275$.
} 
On the instrumental function of law with regard to social change

\section{By Klaus LenK}

Law is often regarded as an instrument for inducing social change by influencing the behavior of its adressees. Such a view is partly due to lack of clearness of the concept of law. Positive law, as enacted by the political power, is not always kept distinct from feelings of justice, social norms, or other phenomena which in many contexts are considered as legal ones.

As an instrument of social change, law is part of the body of instrumental law dealing with social administration in the broadest sense. Unlike the traditional "lawyers' law" - which may also be formally enacted by the State - it is not yet paralleled by actually observed social bhavior. Empirical research on the effectiveness of law indicates that, unless new legal precepts are deemed reasonable by their addressees, their efficacy relies on fears of coercive sanctions, as well as on the legitimacy of the State supporting and enforcing them. To some extent, this legitimacy is strengthened by the new instrumental law being incorporated into the "lawyers' law".

Stressing the role of the law as an instrument of social change was characteristic of the now vanishing normative climate of the "Obrigkeitsstaat" where laws were obeyed simply because they were laws emanating from the State. Such a view is inappropriate for a general assessment of the contribution of law in politically induced processes of social change where the use of legal precepts, while still constituting a privileged means of communication, cannot substitute the broad conviction of the changes to be brought about.

\section{Control and Management of the Economy: Research Perspectives on Public Enterprise}

\section{By Yash GHaI}

The paper suggests some perspectives for research into public enterprise. The main argument is that only a limited understanding of public enterprise can be obtained from a study of the texts of legislation and the case law. It is essential to relate public enterprise to the broader social and political system in which the enterprise functions. Some particular perspectives which are discussed seek to relate the role of public enterprise to the internal class structures of the country in question, as well as to the international context. As to the former, it is argued that public enterprise is used to benefit particular groups in society, and that often their effect may be strength to the private sector activities (and interests) rather than to bring about any kind of socialist transformation. The international context is important because of the heavy dependence of the most developing countries on the Western group of countries, and because of the argument that a primary cause of the backwardness of the developing countries is their exploitation by the industrialised countries. Public enterprise provides a useful vehicle through which to examine the links and the relationships between the international capitalist system 
and the domestic economy, as public enterprises have increasingly emerged as the main forms of joint ventures. Many public enterprises are this forms for at least partially private investment.

The paper also examines the relationship between public enterprises and the national economic plan. It looks at the case of grants of wider and wider discretionary powers to bureaucrats and administrators, and suggests some implications of this on the legal system, which is traditionally conceived in terms of rules and standards. Finally the paper suggests the various ways in which the emergence of public enterprise has affected the legal system, and the effect the legal system has had on public enterprise. There have been few systematic studies of the subject, so that our knowledge is patchy and superficial. As public enterprise becomes one of the major institutions for industry, finance and commerce, and as it increases in importance in political and constitutional terms, the regulation of it by and its accommodation within, the legal system becomes an urgent question, calling for intelligent research in this area.

\section{Africa and the New International Economic Order}

\section{By Zdenek Cervenka}

The article begins with examining the reasons for why the Organization of African Unity had been paying little attention to the economic problems of Africa despite the fact that it had been originally intended to provide a basis for inter-African co-operation in the economic field. Using the East African Economic Community as an example, the author concludes that no meaningful economic co-operation is possible in the absence of political unity of all partners involved.

A section on the relationship between OAU and ECA (Economic Commission for Africa) describes the competition between the two organisations, for economic leadership in Africa. While OAU succeeded in winning recognition for being "primarily responsible", it was the ECA which still did most of the work. The second part of the article gives a background to the rise in demand for the New International Economic Order, the main credit for which goes to Algeria and mentions the recent major conferences devoted to it. The author dwells in more detail on the North-South Dialogue currently continuing in Paris and concludes that the dialogue has so far been dominated by the oil-producing countries on the hand and the industriealized consumers on the other, with Africa playing the role of outsider.

The author concludes that after the 13 years of OAU's existence, the real struggle for the liberation of Africa from the external economic domination has hardly begun. 